\title{
Corporate Governance and Voluntary Risk and Forward-looking Disclosures
}

\author{
Mohammed Elgammal \\ College of Business and Economics, Qatar University, Qatar \\ m.elgammal@qu.edu.qa \\ Khaled Hussainey \\ University of Portsmouth, England, UK \\ Khaled.Hussainey@port.ac.uk \\ Fatma Ahmed \\ Swansea University, Wales, UK \\ F.E.Z.E.AHMED.968524@ @wansea.ac.uk
}

\section{Acknowledgment}

The authors would like to thank the editor of JAAR (Dr. Julia Mundy) and two anonymous referees for helpful comments on this research. We gratefully acknowledge the financial support from the Qatar National Research Fund ((NPRP7-364 -5-048). The statements made herein are solely the responsibility of the authors. 


\begin{abstract}
Purpose: We examine the impact of corporate governance on risk and forward-looking disclosures in Qatar.

Design: We automatically measure levels of risk and forward-looking disclosures in the annual reports of Qatari firms for the period 2008-2014. We also use two ways clustered error pooled panel regressions to examine the determinants of these disclosures.

Findings: We find that firms with a higher percentage of foreign ownership disclose more forward-looking information; conversely, board size has a negative impact on the forward-looking disclosure. Financial firms tend to disclose less forward-looking information, however, they tend to disclose more forward-looking information after the 2008 global financial crisis. We also find negative relationships between the risk disclosure and both the number of non-executive members of the board of directors and duality role of the CEO.

Research implications: Our findings should help the users of corporate annual reports in Qatar to understand managerial incentives for reporting risk and forward-looking information. This should help regulators to set a proper set of disclosure rules. Moreover, this study increases our understanding of the behavior of international investors and the board characteristics (i.e. board size) in motivating risk and forward-looking disclosures in Qatari firms.

Originality: We provide the original empirical evidence on the impact of corporate ownership and board characteristics on risk and forward-looking disclosures for Qatari firms using two ways clustered error pooled panel regressions.
\end{abstract}

Keywords: Risk disclosure, Forward-looking disclosure, Corporate governance, Qatar

JEL classification :G15, G32, G170, M41 


\section{Introduction}

We investigate the impact of corporate governance on risk and forward-looking disclosures in Qatar. Although there is a considerable research on the impact of governance on risk and forward-looking disclosures in the UK and the US, little research has been done in developing countries. Developing markets are different from the UK and the US markets from many aspects including the market size, number of investors, number of listed firms, corporate governance codes, ownership structure in firms and different developmental stage. We, therefore, expect that determinants of voluntary disclosures for the developing countries might not be the same as the developed countries. This motivates us to test if governance mechanisms affect risk and forwardlooking disclosures in a developing country.

Literature shows that risk disclosure vary across the GCC countries despite sociocultural and regulatory similarities (Abdallah et al., 2015) and Qatari firms report more forward-looking information compared to firms in other GCC firms (Mohamed \& Basuony (2014)). This motivates us to examine disclosure practice in Qatar. The integration of the Qatari market with the global economic system increases the need for more non-financial information (i.e. risk and forward-looking information). Therefore, we measure the levels of this type of information and its determinants in Qatar.

Qatar is one of the wealthiest countries in the world in terms of GDP per capita US\$ 94,744. The GDP Growth Rate in Qatar averaged 3.56 percent from 2004 until 2015. Qatar's economy is highly dependent oil and gas extraction, it is the second largest gas reserves in the world representing more than $5 \%$ of the world total (Qatar Statistics Authority, World Bank). In addition, the Qatari banking system is the third largest banking system in the GCC region although it is one of the smallest countries in term of population and geographical area (Hossain et al., 2012). The rapid economic growth in Qatar creates a need to develop the investor protection environment by improving financial regulation for financial reporting. In addition, the new governance code issued in February 2009 by the Qatar Financial Markets Authority (QFMA) offers an opportunity to study the impact of governance on risk and forward looking disclosures. This requires a 
development for investor protection through enhancing the governance environment which is part of the strategic plan for this country (2030). Finally, the Qatari stock market is important as one of the attractive destination for foreign investments for being one of the major gas exporter and the huge expanding in the economy since 2009. This economic growth attracts foreign investors who demand more risk and forwardlooking disclosures.

We offer new evidence on the impact of corporate governance on risk and forward-looking disclosures in Qatar. Prior research shows that an optimal system of governance for all firms and all countries is nonexistent (Castrillo et al., 2010), therefore “one size does not fit all” (Abdallah and Ismail, 2017) and corporate governance influence on voluntary disclosure can be different from market to another. This creates a need for more research on the impact of governance on voluntary disclosure. Prior research on the determinants of risk and forward-looking disclosures use limited governance mechanisms (see Hussainey and Al-Najjar, 2011; Elshandidy et al, 2013 and Al-Maghzom, et al., 2016). In our paper, we hand-collect a comprehensive set of governance variables for all listed firms in Qatar stock exchange. This should inform policy makers about which governance mechanism motivates Qatari companies to disclose risk and forwardlooking information in their annual reports. This is important because "the full adoption of governance practices and transparency measures still faces challenges as a result of the conservative and protectionist investment culture in Qatar which is manifested by weak disclosure of information, and unwillingness to relinquish ownership and control by large block-holders” (Abdallah and Ismail, 2016) .

We also offer a methodological contribution. We use Nvivo 11 software to calculate the number of risk and forward-looking statements in annual report narratives in Qatar. We also use the two ways clustered error pooled panel regression method to examine the determinants of disclosures of these statements. The panel regression method removes the combined firm-year effects on the dependent variable producing more precise results. 
The reminder of the paper is as follows. Section 2 reviews the literature and develops the hypotheses. Research design and method are discussed in Section 3. Section 4 presents the empirical analysis. Section 5 concludes.

\section{Literature Review and Hypotheses Development}

\subsection{Literature Review}

A number of studies have examined the determinants of risk disclosure. In a cross-country study, Elshandidy et al (2015) find that systematic risk, the legal system and the cultural values affect the variations in risk disclosure levels. Elshandidy and Neri (2015) find that corporate governance affect companies' decision to disclosure risk information in annual reports. They considered a number of governance variables such as board size, non-executive directors; independent non-executive directors; CEO duality and concentrated ownership. Barakat and Hussainey (2013) find that board independence, ownership type and active audit committee members are the key drivers of risk disclosure. Al-Hadi et al (2016) find that the existence of ruling family board members negatively affects levels of risk information, especially during financial distress and when their levels of risk are high. Using a single country data, Elshandidy et al (2013) find that systematic risk, financing risk, risk-adjusted returns, firm size, dividend yield, the proportion of nonexecutive directors, insider ownership and effective audit environment affect levels of risk disclosure. AlMaghzom, et al., (2016) find that the external ownership, audit committee meetings, gender and board size influence levels of risk disclosure. Allini et al (2016) find that the presence of women on the board, the age of the board members and the board expertise are the main determinants of risk disclosure. There is, however, very little research reported on the impact of governance on risk disclosure in the developing countries. Our paper fills this gap.

A number of studies have examined the determinants of forward-looking disclosure. For example, Karamanou and Vafeas (2005) find that the corporate governance affects earnings forecasts voluntary disclosure. Hussainey and Al-Najjar (2011) find that firm size, profitability, board independence and insider 
ownership are the main determinants of forward-looking disclosure. Aljifri et al (2013) find that institutional and governmental ownership are the main drivers of forward-looking disclosure. Wang and Hussainey (2013) find that directors' ownership, board size, board composition, and CEO duality are the main factors that drive UK managers to voluntarily disclose forward-looking information. Athanasakou and Hussainey (2004) find that firm-specific characteristics such as levels of forward looking disclosure last year, growth rate, bookmarket ratio, number of analysts following the company; firm size, leverage and profitability affect levels of forward-looking disclosure. There is, however, very little research reported on the impact of corporate governance on forward-looking disclosure in the developing countries. Our paper fills this gap.

Our paper differs from the above-mentioned literature in a number of ways. We examine the impact of governance on both risk and forward-looking disclosure Qatar. We use a comprehensive set of governance variables. Methodologically, we use Nvivo 11 software to measure risk and forward-looking disclosure scores. We apply the two ways clustered error pooled regression model to investigate the relationship between corporate governance and disclosures. The two ways clustered error pooled regression model control for any measurement error or misspecification. Our method removes the combined firm-year effects on the dependent variable and reduces the bias in standard errors. This methodology offers us a better understanding for the association between governance and voluntary risk and forward-looking statements. Furthermore, our study focuses on the Qatari market, which is different from previous studies' samples with respect to the size and the ownership concentration, restrictions on foreign ownership, recent corporate governance code, and the GDP per capita. These differences make us believe that the relationship between corporate governance and disclosures in Qatar might be different compared with the findings of developing countries.

\subsection{Hypotheses Development}

Agency theory is frequently used in prior research to develop the hypothesised relation between governance and voluntary disclosure. The role of voluntary disclosure is crucial in stock markets in general and in the stock markets of the developing countries in particular. As mentioned in Healy and Palepu (2001) 
lack of disclosure impedes the efficient allocation of resources in a capital market economy. In the context of agency theory, conflicts of interests and agency costs are expected to arise when there is incomplete and asymmetric information problem between principal and agent in a company (Jensen and Meckling, 1976). One mechanism to reduce the information asymmetry and agency costs problems is to encourage companies to increase their levels of relevant information to investors. Another mechanism to reduce these problems is the existence of a good corporate governance system. Prior research shows that high-levels of voluntary disclosure and good corporate governance system are complementary mechanisms to mitigate agency problems and reduce information asymmetry (Baek et al., 2009; Cerbioni and Parbonetti, 2007). In the present study, we use agency theory in the development of our research hypotheses.

\subsubsection{Foreign Ownership}

El-Gazzar, (1998) argues that firms with a foreign ownership are probably disclosing more voluntary information. This argument has been supported by the empirical work of Xiao, et al., (2004) who find a positive association between foreign ownership and earnings forecasts in the Chinese firms. In the same line Ferguson et al. (2002) find out that foreign ownership has significant positive effects on voluntary disclosure. Foreign shareholders may suffer from high level of information asymmetry caused by language and law constraints and lack of information availability. Based on the agency theory, one possible way to reduce the level of information asymmetry is to increase levels of voluntary disclosure. Empirically, Mangena and Tauringana (2007) and Bokpin and Isshaq (2009) find a relation between foreign investors and disclosure in developing countries. We, therefore, expect that policy-makers in Qatar will be keen to improve the liquidity of the stock market through foreign ownership. Consequently, Qatari companies with high level of foreign ownership are most likely to disclose more risk and forward-looking disclosure to reduce the information asymmetry. Consequently, we hypothesise that:

H1.1: A positive association exists between foreign ownership and risk disclosure.

H1.2: A positive association exists between foreign ownership and forward-looking disclosure. 


\subsubsection{Board Size}

There is a controversial debate in the literature about the impact of board size on disclosure. On one hand, theoretical papers suggest that boards with a small number of directors might be more effective at monitoring firms' managers and hence companies with a small board size might disclose more information voluntarily (Herman, 1981; Goodstein et al., 1994 and Yermack, 1996). However, the workload of an individual member might be too high and this might negatively affect their ability to effectively monitor firms' managers. On the other hand, large boards are more likely to have a more diversified range of expertise than smaller boards and this might increase the effectiveness of the monitoring power of the board and then we expect that firms with a large number of boards will disclose more voluntary disclosure. Empirically, prior research reports a positive relationship between board size and risk disclosure (see, for example, Elshandidy et al, 2013; Elshandidy and Nero, 2015; Al-Maghzom, et al., 2016) and also between board size and forwardlooking disclosure (see, for example, Wang and Hussainey, 2013).

We, therefore, treat the impact of board size on risk and forward-looking disclosures as a purely empirical research question in the Qatari context and we hypothesise that:

H2.1: Board size has a positive association with risk disclosure.

H2.2: Board size has a positive association with forward-looking disclosure.

\subsubsection{Board Composition}

Kanagaretnam et al., 2007 among others suggest that increasing the ratio of non-executive board members reduces information asymmetry and leads to an increase in the levels of corporate disclosure. However, the association between board composition and voluntary disclosure vary with the data used in different countries (for example; Eng and Mak, 2003; Mangena and Pike, 2005; Barako et al., 2006; Boesso and Kumar, 2007; Hoitash et al., 2009). Based on the agency theory, non-executive directors can play a vital 
role in monitoring managers' performance and motivate managers to disclose more forward-looking information (Wang and Hussainey, 2013). Samaha, et al (2015) use a meta-analysis a sample of 64 empirical studies and find that board composition has a significant positive effect on voluntary disclosure. Hussainey and Al-Najjar (2011) and Wang and Hussainey (2013) find that board independence affect levels of forwardlooking disclosure while Elshandidy et al (2013) find that board independence affect levels of risk disclosure. We, therefore, hypothesise that:

H3.1: There is a positive association between proportion of non-executive and risk disclosure

H3.2: There is a positive association between proportion of non-executive and forward-looking disclosure.

\subsubsection{Role Duality}

Role duality exists when the CEO is also acting as the chair of the board of directors. This situation may create advantages and disadvantages. On the disadvantages side, Wang and Hussainey (2013) argue that the role duality may reduce the effective control, enable the CEO to engage in opportunistic behavior. Therefore, we expect a negative relationship between role duality and voluntary disclosure of risk and forward-looking disclosure. Brickley et al. (1997), however, suggest three benefits for the role duality: quick actions, more relevant and timely decisions, strong leadership style. We believe that these benefits may enhance the managerial efficiency but not necessarily lead to higher levels of risk and forward-looking disclosures. Literature on the impact of CEO duality on disclosure is mixed. For example, Elshandidy et al (2013) find that CEO duality does not affect level of risk information, while Hussainey and Wang (2013) find that CEO duality affect levels of forward-looking disclosure. Disclosure literature, in general, shows that the role duality is negatively associated with voluntary disclosure (see for example Lakhal (2005) and Samaha et al (2015)). We, therefore, hypotheses that:

H4.1 CEO duality is negatively associated with risk disclosure.

H4.2 CEO duality is negatively associated with forward-looking disclosure. 


\subsubsection{Control variables}

Following relevant literature we control for firm size (Al-Najjar and Hussainey, 2011; Wang and Hussainey, 2013; Elshandidy et al, 2013; Althanasakou and Hussainey, 2014; Elshandidy and Nero, 2015; Allini et al, 2016; Elshandidy and Shrives, 2016); firm growth rate (Hussainey and Al-Najjar, 2011; Elshandidy et al, 2013; Athanasakou and Hussainey, 2014 and Elshandidy and Shrives, 2016) leverage (Abraham and Cox, 2007; O’Sullivan et al., 2008; Wang and Hussainey, 2013; Athanasakou and Hussainey, 2014; Elshandidy, et al, 2015; Elshandidy and Nero, 2015; Elshandidy and Shrives, 2016); dividend (Hussainey and Al-Najjar, 2011; Wang and Hussainey, 2013; Elshandidy et al 2013; Elshandidy and Neri (2015); profitability (Hussainey and Al-Najjar, 2011; Elshandidy et al 2013; Wang and Hussainey, 2013; Athanasakou and Hussainey 2014; Allini, et al., 2016; Elshandidy and Shrives, 2016).

\section{Research design and methods}

\subsection{Regression models}

Following Peterson (2009), we apply two ways clustered error pooled regression model to control for any measurement error or misspecification that may naturally "induce" spurious group-level shocks and correlation in errors. If the residuals are correlated across firms the OLS standard errors (SE) can be biased, which might lead to an incorrect inference of the estimated coefficients (Hoechle 2007 and Petersen 2009). We include firm and year dummies to consider for measurement errors, and the effect of heterogeneity in the sample, as well as to control for omitted variable bias in the model. We use the following regression models:

$$
\begin{aligned}
& \quad D S_{i, t}=\alpha_{0}+\alpha_{1} F D U M_{i, t}+\alpha_{2} F O_{i, t}+\alpha_{3} B S_{i, t}+\alpha_{4} B C_{i, t}+\alpha_{5} \text { Duality }_{, t}+\alpha_{6} D Y_{i, t}+\alpha_{7} F S_{i, t}+\alpha_{8} R O E_{i, t} \\
& \quad+\alpha_{9} L E V_{i, t}+\alpha_{10} M B_{i, t}+\alpha_{11} F C_{i, t}+\varepsilon_{i, t} \\
& D S_{i, t}=\beta_{0}+\sum_{n=1}^{7} \beta_{1+n} I N D_{n}+\beta_{2} F O_{i, t}+\beta_{3} B S_{i, t}+\beta_{4} B C_{i, t}+\beta_{5} \text { Duality }_{i, t}+\beta_{6} D Y_{i, t}+\beta_{7} F S_{i, t}+\beta_{8} R O E_{i, t} \\
& +\beta_{9} L E V_{i, t}+\beta_{10} M B_{i, t}+\beta_{11} F C_{i, t}+\mathcal{E}_{i, t}
\end{aligned}
$$


$D S$ represents our disclosure measure risk information $(\mathrm{R})$ and forward-looking information $(\mathrm{F})$. The intercepts are $\alpha$ and $\beta$ in model 1 and 2 respectively. FDUMY is a dummy variable (used only in model 1) defined to be one for firms belong to banking or insurance sectors and zero otherwise. Model 2 examines the industry effect using a set of 7 dummy variables (IND) which takes value 1 if the firm belongs to the industry and take the value 0 otherwise. As Qatar exchanges has eight sectors, we consider 7 dummy variables and we use the Telecom sector as a reference sector. $F O$ is the ratio of foreign ownership in the each firm. $B S$ (board size) is the log of the total number of directors on the board. $B C$ (board composition) is the percentage of nonexecutive directors, that is, the number of non-executive directors divided by the board size. Duality is a dummy variable for role duality (1 for duality and zero for separation). $D Y$ (dividend) is the dividend yield. $F S$ (firm size) is the natural logarithm of the market capitalization. ROE (profitability) is the return on Equity; ${ }^{1}$ and $L E V$ is the leverage ratio (total debt / total assets); $M B$ is market to book ratio; and $F C$ is a dummy variable for the last financial crisis (1 if the observation in years 2008 and 2009 and 0 otherwise). Table 1 provides the description for our variables.

\section{Table 1 about here}

In the above models, the $(F O)$ captures the ownership structure while three explanatory variables $(B S$, $B C$, and Duality) capture the board characteristics. $F O$ shows the ownership concentration for foreign investors who are expected to be effective external monitors of managerial discretion in financial reporting, as they are mainly institutions. If our first hypothesis holds, the coefficients $\alpha_{2}$ and $\beta_{2}$ should be positive. The $B S$ is the total number of directors on the board. The larger the board the more likely that the board encourages greater disclosure of future-oriented information in the annual reports. Therefore, we expect the coefficients $\alpha_{3}$ and $\beta_{3}$ to be positive. The $B C$ measures the proportion of non-executive directors on the board. Cadbury (1992), among others, report that the non-executive directors can effectively enhance the transparency of the firm which leads us to expect the disclosure score to be positively associated with $B C$ and, therefore, we expect

\footnotetext{
${ }^{1}$ The ROE is a traditional variable used in the research as a proxy for profitability. Following Eng and Mak (2003) we use also ROA as a robustness test and find consistent results. Results are available upon request.
} 
coefficients $\alpha_{4}$ and $\beta_{4}$ to be positive. Duality measures whether the chairperson also has the role of corporate CEO or not. Under duality, the firm's management has greater power over the board's decision-making process; and, hence, the firm might be less likely to voluntarily disclose a large amount of forward-looking information in its annual reports. Therefore, we expect the coefficients $\alpha_{5}$ and $\beta_{5}$ to be negative. Other control variables are proxies for the remaining firm characteristics.

\subsection{Data}

Our dataset includes all firms (43 firms) listed on the Qatar Stock Exchange from 2008 to 2014. Our motivations to choose this period are as follows. First, it is the time after the last financial crisis. Second this period allowed to us to study the impact of new governance code in Qatar (2009) on risk and forward-looking disclosure. Finally, we have to admit that it is not easy to find complete annual reports for all listed firms in Qatar before 2008. Although Qatar Exchange (previously known as Doha Securities Market) started in 1997, the trade volume and number of listed firms increased dramatically after 2003 and most of the listed firms have its full annual reports from 2008 .

Unlike the previous research, we include financial firms in our analysis because the financial sector is the biggest sector in Qatar Exchange (34.32\% from the 42 listed firms). Therefore, we separate our sample to two sub samples considering both non-financial and financial firms. We downloaded the annual reports for the sample firms from the Qatar Exchange web site, gulf base and Bloomberg databases. We convert these reports into text format. We use NVivo 11 software to calculate the number of risk and forward-looking statements. QSR NVivo software has recently been used widely in the literature to measure levels of risk disclosure (e.g. Elshandidy et al, 2013; Elshandidy et al, 2015) and forward-looking disclosure (e.g. Wang and Hussainey, 2013; Athanasakou, and Hussainey, 2014; Hassanein and Hussainey, 2015 \& Hassanien et al, 2018). We apply some filtering procedures according to the data availability. Firms that do not have full annual reports for the study period from 2008 to 2014 are excluded from our sample. Therefore, our final sample is 35 listed companies (245 firm-year observations). 


\subsection{Measuring the levels of risk and forward-looking statements}

Our dependent variables are risk and forward- looking disclosures. We follow recent disclosure studies to measure the risk disclosure. Elshandidy et al $(2013 ; 2015)$ measure risk disclosure in three steps. First, they use prior academic and professional research on risk concepts. They also use Roget's Thesaurus dictionary and annual reports to identify a comprehensive list of key words. Second, they check for the ability of these words to capture the risk statements. They eliminated all keywords that do not capture risk information in their pilot study of a small sample of annual reports. Finally, they check for the reliability and validity of their final list of risk words. They use the following keywords for measuring total risk disclosure: risk*, loss*, decline (declined), decrease (decreased), less, low*, fail (failure), threat, verse (versed; reverse; reversed), viable, against, catastrophe (catastrophic), shortage, unable, challenge (challenges), uncertain (uncertainty; uncertainties), gain (gains), chance (chances), increase (increased), peak (peaked), fluctuate*, differ*, diversify*, probable* and significant*.Words denoted by * also include derivatives of the original. To capture the mandatory risk disclosure, they use the following keywords: derivatives, financial instruments, investments, segments and foreign currency. Differences between total risk disclosure score and mandatory disclosure score represent the level of voluntary risk disclosure. We use the Nvivo 11 software, developed by QSR International, to identify the number of sentences that contain at least one risk keyword.

Following Wang and Hussainey (2013), we use the computer-based content analysis procedure developed by Hussainey et al. (2003) to identify the number of forward-looking statements. These keywords are: accelerate, anticipate, await, coming (financial) year(s), coming months, confidence (or confident), convince, (current) financial year, envisage, estimate, eventual, expect, forecast, forthcoming, hope, intend (or intention), likely (or unlikely), look forward (or look ahead), next, novel, optimistic, outlook, planned (or planning), predict, prospect, remain, renew, scope for (or scope to), shall, shortly, should, soon, will, well placed (or well positioned), and year(s) ahead. Like Hussainey et al. (2003) we take the future year numbers into account in the list of keywords for the forward-looking content related to earnings forecasts. 
A disclosure score has been generated for the sample through two steps. In the first step, we examine the narrative sections of the annual reports for forward-looking information, because these sections are more likely to contain this type of information. Next, we use the Nvivo version 11 software to identify the number of sentences that contain at least one forward-looking keyword.

\section{Empirical analysis}

Table 2 provides the descriptive statistics. The highest forward-looking disclosure score is 170 statements while the lowest is two statements. This indicates that significant variation in disclosure practice exists between Qatari firms. Similarly, the highest risk disclosure score of the sampled firms is 189 statements while the lowest is one statement.

The average firm has $47.7 \%$ of total debt of total assets. The median of leverage is 45.9 percent with a standard deviation 26.12. This indicates that our sample consists of reasonably geared firms with a little variation in the financial leverage. The mean of the market to book ratio is 1.99 suggesting that our sample includes well-preformed firms with a moderate dispersion exists among observations with regard to their market to book ratio. Furthermore, the average return on equity is $5.3 \%$ with a maximum of $57.87 \%$ and a minimum of $-25.07 \%$ and the standard deviation is about 1.61 . These results show that firms in our sample are fairly performing well during the period of our analysis on average. Finally, on average, firms pay dividends of $4 \%$ with relatively low dispersion 2.8 .

The mean non-executive directors on board ratio is 0.43 and the highest value of .88 . The mean market capitalization of the firms in the sample is 28 billion Qatari Riyal with a maximum of 486 billion and only a minimum of 283 million. The average return on assets is 6.7 with a maximum of $29.96 \%$ and a minimum of 6.22 this indicating that the firms are well performed in terms of profitability measured by return on assets. A few extremely large firms skew market capitalization and its mean is much higher than the median. Therefore, we use the natural logarithm of the market capitalization to reduce this skewness. Similarly, we measure the 
variable BS as the natural logarithm of the total number of directors. Shapiro and Wilk's (1965) test has been applied and shows that our variables are normally distributed.

\section{Table 2 about here}

Table 3 presents Pearson correlation. The correlation between forward-looking disclosure and risk disclosure is $47 \%$ significant at the $1 \%$ level. Only the correlation coefficient between risk disclosure $(R)$ and firm size $(F S)$ is relatively high. Risk disclosure is also correlated with dividend yield, leverage and market-tobook ratio. The correlation between the independent variables is less than 0.70 , suggesting that there is no multicollinearity problem. Our measure for the disclosure of forward-looking statements is not correlated statistically with all of the corporate governance except foreign ownership (FO). The disclosure of forwardlooking statements is statistically correlated with all of the firm characteristics variables except for market to book ratio $(M B)$ and the return on equity $(R O E)$.

\section{Table 3 about here}

Table 4 reports the two ways clustered error pooled regression models (1) and (2). Columns 2 and 3 show the findings of model (1), while Columns 4 and 5 show the findings of model (2).

The third and fifth columns of table 4 present the findings of model (1) and (2) related to the determinants of risk disclosure. We did not find any significant relationships between risk disclosure and any governance variables (i.e. foreign ownership; board size; board composition; CEO duality role) and therefore we reject hypotheses $1.1,2.1,3.1$, and 4.1 respectively. These findings suggest that the quality of corporate governance system does not affect the companies' decision to report risk information in their annual reports.

Looking at our control variables, we find that market to book ratio, firm size and profitability affect the levels of risk disclosure. The results indicate that large firms with a high market to book (higher growth opportunity firms) and high levered firms is motivated to disclose more about their risks compared to other firms. We did not find an industry effect on the risk disclosure of Qatari firms, this is not in line with Khlif and Hussainey (2016) who find that relation between profitability and risk disclosure is affected by industry type. 
Our findings suggest that some firm-specific characteristics (not corporate governance) affect the level of risk disclosure in the Qatari context.

The second and fourth columns of table 4 present the findings of model (1) and (2) related to the determinants of forward-looking disclosure. The second column shows that board size, foreign ownership, profitability, firm size, and leverage affect the levels of forward looking disclosure. The coefficient of the foreign ownership is positive and significant at the $1 \%$ level. Therefore, we cannot reject Hypothesis 1.2. Foreign investors, who typically hold around $28 \%$ of the shares in Qatari firms, is positively associated with the level of forward-looking disclosure. This suggests that firms owned by international investors are more motivated to enhance the quantity of the voluntary disclosure related to the future to maintain their international shareholders as they have more probability to move away if they do not have enough information about the future prospects of the company.

Columns 2 and 4 of Table 4 show that there is a negative association between forward-looking statements and board size. This finding suggests that the smaller number of directors in the board the higher the level of voluntary disclosure related to the future. Therefore, the finding supports Hypothesis 2.2. This result is consistent with a trend in the literature that argues that boards with a small number of directors might be more effective in monitoring firms' managers. Hence, companies with small board size are expected to disclose more forward looking /risk information (Herman, 1981; Goodstein et al., 1994 and Yermack (1996).

We did not find any significant relationship between forward-looking disclosure and either the percentage of non-executive directors sitting on the board or CEO role duality. Therefore, we reject hypotheses 3.2 and 4.2. These findings suggest that non-executive directors in the Qatari firms may not have the adequate expertise and knowledge to effectively influence the forward-looking disclosure practice to the best interest of their companies. In addition, the findings suggest that the division of responsibilities between the role of the Chairman and CEO is clear in Qatari companies and no one person has unfettered power to take decisions. 
The controlled firms' characteristics, that is, firm size, profitability, and leverage ratio are significant, suggesting that large, profitable and highly geared firms disclose more forward-looking disclosure. We did not find an association between dividend yield and market to book ratios and the level of forward-looking disclosure, suggesting that Qatari companies do not use dividend as a substitute for forward-looking disclosure to signal their good performance. The findings also suggest that the status of corporate growth (high or low growth) does not also the affect level of forward-looking disclosure.

Finally, we find a negative association between forward-looking disclosure and the financial sector dummy variable. These results may suggest that financial firms tend to disclose less information about their future compared to non-financial firms to avoid any potential litigation costs.

Overall, it seems that Qatari companies try to attract foreign investors by disclosing more forwardlooking information and the board of directors support this disclosure practice. However, these companies have the fear of the negative consequences of reporting risk related information in their annual reports (i.e. low share price; lower firm value; higher cost of capital).

\section{Table 4 about here}

\section{Financial Vs Nonfinancial firms}

This section investigates if the motivations for both forward-looking and risk disclosure are different between financial and nonfinancial Qatari firms. Table 5 panel A presents the results of model 1 using the data of financial firms (126 firm/year observations). The results of regressing the forward-looking disclosure on corporate governance variables and firm characteristics are very similar to our previous results of the whole sample. The board size, foreign ownership, firm size, and financial leverage can explain the variation in forward-looking disclosure. We have got some new findings here. Profitability is now insignificant. These results are consistent with Hossain and Hammami, (2009) who explore the determinants of voluntary disclosure in the annual reports of 25 listed firms of Doha Securities Market. Hossain and Hammami, (2009) report that profitability cannot explain voluntary disclosure where the board size does. In addition, financial crisis variable 
is now significant (and still negative), suggesting that Qatari companies disclose less forward-looking information after the global financial crisis. The results reported in the second columns in Table 5 Panel A did not show any significant relationships between risk disclosure and either foreign ownership, or board size. We, however, find a negative relationship between risk disclosure and both the number of non-executive directors and CEO duality. Finally, Table 5 Panel A shows that risk disclosure can be explained by leverage, firm size, and profitability.

The results of nonfinancial firms in panel B of table 5 are less significant compared to the financial firms. We have found only a significant relationship between foreign ownership and forward-looking disclosure. This support our previous findings that firms with high level of foreign ownership disclose more about their future. The puzzle is that we find a negative association between the firm size and forward looking disclosure that is contradicting with our expectation. It suggests that small non-financial firms tend to show more about its financial plans to attract investors. Furthermore, Table 5 shows that the risk disclosure scores increase in nonfinancial profitable, levered, and value firms (low market to book ratio) compared to other non-financial firms.

\section{Table 5 about here}

\section{Conclusion}

We used the computerised content analysis to analyse the annual report of a sample of Qatari listed companies from 2008 to 2014. We then used the two ways clustered error pooled panel regressions to find which governance mechanism affect risk and forward-looking disclosures. We found that the foreign ownership has a positive effect on forward-looking disclosure, while board size has a negative impact. We also found that financial firms tend to disclose less information about their future plans compared to nonfinancial firms, however, they tend to disclose more information about their future plans after the last financial crisis. In addition, we found significant negative relationships between the risk disclosure index and both the number of non-executive members in the board of directors and CEO. 
Our findings have practical implications. It shows that the effectiveness of corporate governance code in promoting transparency in Qatar. Qatar Governance Code has been issued in 2009, the path to effective corporate governance practice still needs to be investigated. Our results suggested that Qatari policy-makers and regulators need to consider the importance of foreign ownership, duality, board size, and board composition to increase the quality of voluntary disclosure for risk and looking-forward information. Our findings also might encourage investors to invest in firms with higher foreign ownership ratio, non-executive members ratio, and no duality with a small number of board directors if they are looking for more transparent companies (i.e. more risk and forward-looking disclosures). Because of the economic growth in Qatar is rapidly increasing, our findings suggest that hard work is needed to improve the quality of corporate reporting as well as the quality of governance as a part of the Qatari new strategic plan 2030.

Our study has two main limitations. First the limited availability of Qatari firms corporate governance data before 2012 which lead us to remove some firms from our analysis and to end with a small number of observations. The second limitation is that we study the determinants of disclosure (the supply side of the financial communication), but we ignore the demand side of the financial communication (i.e. the impact of disclosure on stakeholders).

We offer avenues for further research. Future research may explore the value relevance and the economic consequences of risk and forward-looking disclosures in the Qatari annual reports. Second cross-country" studies can be undertaken to examine the economic consequences of risk disclosure for a sample of Middle Eastern countries. Furthermore, how board's role may affect risk disclosure within specific industry sectors merit further attention.

\section{References}

Abdallah, A. A. N., Hassan, M. K., \& McClelland, P. L. 2015. "Islamic financial institutions, corporate governance, and corporate risk disclosure in Gulf Cooperation Council countries". Journal of Multinational Financial Management, Vol 31, pp. 6382. 
Abdallah, A. and Ismail, A., 2017 "Corporate governance practices, ownership structure, and corporate performance in the GCC countries." Journal of International Financial Markets, Institutions and Money, Vol 46, pp. 98-115.

Abraham, S. and Cox, P., 2007, "Analysing the determinants of narrative risk information in UK FTSE 100 annual reports", The British Accounting Review, Vol 39, No 3, pp.227-248.

Al-Hadi, A., Grantly, T and Al-Yahyaee, H. 2016. "Ruling family political connections and risk reporting: Evidence from the GCC. The International Journal of Accounting, Vol 51, No 4, pp. 504-524.

Aljifri, K., Hussainey, K. and Oyelere, P. 2013. "The determinants of relevant information disclosure: A corporate governance perspective", Corporate Ownership and Control, Vol 10, No 2, pp. 8-19.

Allini, A., Manes Rossi, F. and Hussainey, K., 2016. "The board's role in risk disclosure: an exploratory study of Italian listed stateowned enterprises" Public Money \& Management, Vol 36, No 2, pp.113-120.

Al-Maghzom, A., Hussainey, K. and Aly, D.A., 2016. "Corporate governance and risk disclosure: Evidence from Saudi Arabia", Corporate Ownership and Control, Vol 13, No 2. pp. 145-166.

Athanasakou, V. and Hussainey, K. 2014. "The perceived credibility of forward-looking performance disclosures", Accounting and Business Research, Vol 44, No 3, pp. 227-259.

Baek, H.Y, Johnson, D.R. and Kim, J.W. 2009. "Managerial ownership, corporate governance, and voluntary disclosure", Journal of Business and Economic Studies, Vol 15, No 2, pp 44-61.

Barakat, A. and Hussainey, K. 2013. 'Governance and risk reporting: evidence from operational risk disclosures in European banks'. International Review of Financial Analysis, Vol 30, pp. 254-273.

Barako, D.G., Hancock, P. and Izan, H.Y., 2006, "Factors influencing voluntary corporate disclosure by Kenyan companies", Corporate Governance: An International Review, Vol 14, No 2, pp.107-125.

Boesso, G. and Kumar, K., 2007. "Drivers of corporate voluntary disclosure: A framework and empirical evidence from Italy and the United States", Accounting, Auditing \& Accountability Journal, Vol 20, No 2, pp.269-296.

Bokpin, G, Isshaq, Z. 2009 "Corporate governance, disclosure and foreign share ownership on the Ghana Stock Exchange", Managerial Auditing Journal, Vol. 24, No7, pp.688-703.

Brickley, J.A., Coles, J.L. and Jarrell, G., 1997, "Leadership structure: Separating the CEO and chairman of the board", Journal of corporate Finance, Vol 3, No 3, pp.189-220.

Cadbury, A. ,1992, "The code of best practice". Report of the Committee on the Financial Aspects of Corporate Governance, Gee and Co Ltd, 27.

Castrillo, L., Marcos, S., San Martin, J., 2010. "Corporate governance, legal investor protection, and performance in Spain and the United Kingdom". Corporate Ownership Control, Vol 7, No 4, pp. 416-429.

Cerbioni, F. and Parbonetti, A. 2007. "Exploring the effects of corporate governance on intellectual capital disclosure: an analysis of European biotechnology companies", European Accounting Review, Vol 16, No 4, pp 791-826.

Cooke, T.E. 1989. "Disclosure in the Corporate Annual Reports of Swedish Companies". Accounting and Business Research. Vol 19, No74, pp. 113-124.

El-Gazzar, S.M., 1998, "Predisclosure information and institutional ownership: A cross-sectional examination of market revaluations during earnings announcement periods", Accounting Review, Vol 73, No. 1, pp 119-129.

Elshandidy, T., Fraser, I. and Hussainey, K., 2013, “Aggregated, voluntary, and mandatory risk disclosure incentives: Evidence from UK FTSE all-share companies”, International Review of Financial Analysis, Vol 30, pp.320-333. 
Elshandidy, T., Fraser, I. and Hussainey, K., 2015, "What drives mandatory and voluntary risk reporting variations across Germany, UK and US?" The British Accounting Review, Vol 47, No 4, pp.376-394.

Elshandidy, T., and Neri, L. 2015. Corporate Governance, risk disclosure practices, and market liquidity: Comparative evidence from UK and Italy. Corporate Governance: An International Review, Vol 23, No 4, pp. 331,356.

Elshandidy, T., and Shrives, P. 2016. The environmental incentive for and usefulness of textual risk disclosure: The German Evidence, the International Journal of Accounting, Vol 51, No 4, pp. 464-486.

Eng, L.L. and Mak, Y.T., 2003. “Corporate governance and voluntary disclosure”, Journal of accounting and public policy, Vol 22, No 4, pp.325-345.

Ferguson, M. J., Lam, K. C. K., \& Lee, G. M. 2002. "Voluntary disclosure by state-owned enterprise listed on the stock exchange of Hong Kong”. Journal of International Financial Management and Accounting, Vol 13, pp. 125-152.

Goodstein, J., Gautam, K. and Boeker, W., 1994. "The effects of board size and diversity on strategic change”, Strategic Management Journal, Vol 15, No 3, pp.241-250.

Hassanein, A and Hussainey, K. 2015. "Is forward-looking financial disclosure really informative? Evidence from UK narrative statements", International Review of Financial Analysis, Vol 41, pp. 52-61.

Hassanein, A, Zalata, A. and Hussainey, K. (2018). Do forward-looking narratives affect investors' valuation of UK FTSE all-shares non-financial firms? Review of Quantitative Finance and Accounting, forthcoming.

Herman, E.S., 1981. Corporate control, corporate power (Vol. 98, p. 1). Cambridge: Cambridge University Press.

Ho, S.S. and Wong, K.S., 2001. "A study of the relationship between corporate governance structures and the extent of voluntary disclosure" Journal of International Accounting, Auditing and Taxation, Vol 10, No 2, pp.139-156.

Hoechle, D., 2007. "Robust standard errors for panel regressions with cross-sectional dependence", Stata Journal, Vol 7, No 3, p. 281 .

Hoitash, U., Hoitash, R. and Bedard, J.C., 2009. “Corporate governance and internal control over financial reporting: A comparison of regulatory regimes", The Accounting Review, Vol 84, No 3, pp.839-867.

Hossain, M. and Hammami, H., 2009. "Voluntary disclosure in the annual reports of an emerging country: The case of Qatar", Advances in Accounting, Vol 25, No. 2, pp.255-265.

Hossain, M., Momin, M.A. and Leo, S., 2012. "Internet financial reporting and disclosure by listed companies: further evidence from an emerging country", Corporate Ownership \& Control, Vol 9, No 4, pp.351-365.

Hussainey, K. and Al-Najjar, B., 2011. "Future-oriented narrative reporting: determinants and use", Journal of Applied Accounting Research, Vol 12, No 2, pp.123-138.

Hussainey, K., Schleicher, T. and Walker, M., 2003. "Undertaking large-scale disclosure studies when AIMR-FAF ratings are not available: the case of prices leading earnings", Accounting and Business Research, Vol 33, No. 4, pp.275-294.

Jensen, M.C. and Meckling, W.H., 1976. "Theory of the firm: Managerial behavior, agency costs and ownership structure", Journal of Financial Economics, Vol 3, No 4, pp.305-360.

Kanagaretnam, K., Lobo, G.J. and Whalen, D.J., 2007. "Does good corporate governance reduce information asymmetry around quarterly earnings announcements?” Journal of Accounting and Public Policy, Vol 26, No 4, pp.497-522.

Karamanou, I. and Vafeas, N., 2005. "The association between corporate boards, audit committees, and management earnings forecasts: An empirical analysis", Journal of Accounting research, Vol 43, No 3, pp.453-486.

Khlif, H. and Hussainey, K., 2016. "The association between risk disclosure and firm characteristics: a meta-analysis", Journal of Risk Research, Vol 19, No 2, pp.181-211. 
Lakhal, F., 2005. "Voluntary earnings disclosures and corporate governance: Evidence from France", Review of Accounting and Finance, Vol 4, No 3, pp.64-85.

Mangena, M. and Pike, R., 2005. "The effect of audit committee shareholding, financial expertise and size on interim financial disclosures", Accounting and Business Research, Vol 35, No 4, pp.327-349.

Mangena, M. and Tauringana, V. 2007. "Disclosure, corporate governance and foreign share ownership on the Zimbabwe stock exchange", Journal of International Financial Management \& Accounting, Vol 18, No 2, pp.53-85.

Mohamed, E. K., \& Basuony, M. A. 2014. "Determinants and characteristics of voluntary internet disclosures in GCC countries". The International Journal of Digital Accounting Research, Vol. 14, pp. 57-91.

O’Sullivan, M., Percy, M. and Stewart, J., 2008. “Australian evidence on corporate governance attributes and their association with forward-looking information in the annual report", Journal of Management \& Governance, Vol 12, No 1, pp.5-35.

Petersen, M.A., 2009. "Estimating standard errors in finance panel data sets: Comparing approaches", Review of Financial Studies, Vol 22, No 1, pp.435-480.

Samaha, K., Khlif, H. and Hussainey, K., 2015. "The impact of board and audit committee characteristics on voluntary disclosure: a meta-analysis", Journal of International Accounting, Auditing and Taxation, Vol 24, pp.13-28.

Shapiro, S.S. and Wilk, M.B., 1965. "An analysis of variance test for normality (complete samples)", Biometrika, Vol 52, No 3/4, pp.591-611.

Xiao, J.Z., Yang, H. and Chow, C.W., 2004. "The determinants and characteristics of voluntary Internet-based disclosures by listed Chinese companies", Journal of Accounting and Public Policy, Vol 23, No 3, pp.191-225.

Yermack, D., 1996. "Higher market valuation of companies with a small board of directors", Journal of Financial Economics, Vol 40(2), pp.185-211.

Wang, M. and Hussainey, K., 2013. "Voluntary forward-looking statements driven by corporate governance and their value relevance", Journal of Accounting and Public Policy, Vol 32, No 3, pp.26-49.

World Bank Data, "World Bank indicators, GDP Annual Growth”, http://data.worldbank.org/indicator/NY.GDP.MKTP.KD.ZG/countries/QA?display=graph, retrieved on $25^{\text {th }}$ April $26,2016$. 
Table: 1: Variables Definitions

\begin{tabular}{|c|c|}
\hline $\begin{array}{l}\text { Dependent } \\
\text { Variables }\end{array}$ & Proxy \\
\hline $\mathrm{DS}(\mathrm{R} ; \mathrm{F})$ & $\begin{array}{l}\text { DS is the disclosure score. } \mathrm{R} \text { is the number of risk statements, while } \mathrm{F} \text { is the number of forward-looking } \\
\text { statements, }\end{array}$ \\
\hline \multicolumn{2}{|c|}{ Independent Variables } \\
\hline$F O$ & The ratio of foreign ownership. \\
\hline$B S$ & Number of all directors in the board of directors. \\
\hline Duality & Dummy variable (1 for duality and zero for separation). \\
\hline$B C$ & Board composition (the number of non-executive directors divided by the board size). \\
\hline \multicolumn{2}{|c|}{ Control Variables } \\
\hline$D Y$ & Dividend yield \\
\hline$F S$ & Firm size (the natural logarithm of the market capitalization) \\
\hline$R O E$ & Profitability (The return on Equity). \\
\hline$L E V$ & The leverage ratio (total debt / total assets) \\
\hline$M B$ & Market to book ratio \\
\hline$F C$ & Dummy variable for the last financial crisis ( 1 if the observation in years 2008 and 2009 and 0 otherwise) \\
\hline FDUMY & Dummy variable ( 1 if a firm is belong to banking or insurance sectors and 0 otherwise) \\
\hline
\end{tabular}


Table 2 Descriptive Statistic

\begin{tabular}{lllllll}
\hline Variables & Mean. & S.D & Min. & Median. & Max. & Obs. \\
\hline $\boldsymbol{F}$ & 46.56 & 35.59 & 2 & 36 & 170 & 245 \\
$\boldsymbol{B C}$ & 0.43 & 0.38 & 0 & 0.36 & 0.88 & 245 \\
$\boldsymbol{B S}$ & 8.33 & 1.58 & 5 & 8 & 11 & 245 \\
$\boldsymbol{D U} \boldsymbol{L}$ & 0.40 & 0.78 & 0 & 0 & 10 & 245 \\
$\boldsymbol{F D U M}$ & 0.51 & 0.50 & 0 & 1 & 1 & 245 \\
$\boldsymbol{D Y}$ & 4.42 & 2.85 & 0 & 4.38 & 12.14 & 245 \\
$\boldsymbol{F O}$ & 0.28 & 0.19 & 0.08 & 0.25 & 1 & 245 \\
$\boldsymbol{F} \boldsymbol{S}^{2}$ & 28965847 & 61886892 & 283025 & 7237146 & 486000000 & 245 \\
$\boldsymbol{L E} \boldsymbol{V}$ & 47.71 & 26.12 & 0.07 & 45.94 & 100.00 & 245 \\
$\boldsymbol{M B}$ & 1.99 & 1.24 & 0.48 & 1.75 & 13 & 245 \\
$\boldsymbol{R}$ & 42.33 & 43.82 & 1 & 25 & 189 & 245 \\
$\boldsymbol{R O A \%}$ & 6.72 & 5.82 & -6.22 & 5.08 & 29.96 & 245 \\
$\boldsymbol{R O E} \%$ & 5.35 & 1.61 & -25.07 & 14.75 & 57.87 & 245 \\
$\boldsymbol{F C}$ & 0.29 & 0.45 & 0 & 0 & 1 & 245 \\
\hline See Table & 1 for & the variable & definitions & &
\end{tabular}

\footnotetext{
${ }^{2}$ Numbers in thousand Qatari Riyal ( $1 \$=3.65$ QR)
} 
Table 3: Pearson Correlations

\begin{tabular}{|c|c|c|c|c|c|c|c|c|c|c|c|c|c|}
\hline Probability & $F$ & $B C$ & $B S$ & $D U L$ & $F D U M$ & $D Y$ & FO & $F S$ & $L E V$ & $M B$ & $\boldsymbol{R}$ & ROA & $\begin{array}{c}R O \\
E\end{array}$ \\
\hline$F$ & 1 & & & & & & & & & & & & \\
\hline$B C$ & 0.01 & 1 & & & & & & & & & & & \\
\hline$B S$ & -0.07 & 0.05 & 1 & & & & & & & & & & \\
\hline$D U L$ & 0.02 & 0.05 & -0.03 & 1 & & & & & & & & & \\
\hline$F D U M$ & -0.08 & -0.08 & $0.22 * * *$ & 0.03 & 1 & & & & & & & & \\
\hline$D Y$ & 0.01 & -0.09 & $0.33 * * *$ & 0.10 & $0.23 * * *$ & 1 & & & & & & & \\
\hline FO & $0.29 * * *$ & -0.01 & $0.27 * * *$ & -0.01 & 0.02 & 0.07 & 1 & & & & & & \\
\hline$F S$ & $0.29 * * *$ & 0.02 & $0.16 * *$ & $0.15 * *$ & $0.47 * * *$ & $0.19 * * *$ & 0.01 & 1 & & & & & \\
\hline$L E V$ & $0.31 * * *$ & $0.15 * *$ & $0.14 * *$ & $-0.13 * *$ & $0.19 * * *$ & $0.14 * *$ & 0.06 & 0.10 & 1 & & & & \\
\hline$M B$ & -0.01 & 0.11* & $-0.12 *$ & -0.01 & $-0.28 * * *$ & $-0.12 * *$ & $-0.18 * * *$ & 0.01 & $0.12 * *$ & 1 & & & \\
\hline$R$ & $0.47 * * *$ & -0.07 & 0.10 & 0.08 & 0.38*** & $0.12 * *$ & 0.10 & $0.46 * * *$ & $0.34 * * *$ & $-0.13 * *$ & 1 & & \\
\hline$R O A$ & $-0.23 * * *$ & -0.10 & $-0.13 * *$ & $0.14 * *$ & $\mathbf{- 0 . 3 7} * * *$ & 0.05 & $-0.21 * * *$ & $-0.24 * * *$ & $-0.40 * * *$ & $0.26 * * *$ & $\mathbf{- 0 . 3 9} * * *$ & 1 & \\
\hline ROE & -0.01 & -0.09 & 0.05 & 0.04 & 0.05 & $0.11 *$ & 0.01 & 0.03 & $-0.11 *$ & -0.03 & 0.05 & 0.1 & 1 \\
\hline$F C$ & $-0.11 *$ & 0.04 & -0.10 & -0.04 & $-2.80 \mathrm{E}-17$ & $0.15 * *$ & -0.01 & -0.02 & -0.01 & 0.03 & -0.07 & 0.06 & -0.1 \\
\hline
\end{tabular}

See Table 1 for the variable definitions.

$* * *$ denotes $1 \%$, ** denotes $5 \%$, and $*$ denotes $10 \%$ level of significance. 
Table 4: Two Ways Cluster Errors Regression

\begin{tabular}{|c|c|c|c|c|}
\hline & Future disclosure & Risk disclosure & $\begin{array}{c}\text { Future disclosure } \\
\text { industry effect }\end{array}$ & $\begin{array}{l}\text { Risk disclosure } \\
\text { Industry effect }\end{array}$ \\
\hline$F D U M$ & $-0.67 * *$ & 0.26 & & \\
\hline $\boldsymbol{F O}$ & $1.54 * * *$ & 0.44 & 0.62 & 0.91 \\
\hline$B S$ & $-1.00 * * *$ & -0.33 & $-0.57 * * *$ & -0.53 \\
\hline$B C$ & -0.11 & -0.32 & -0.13 & -0.38 \\
\hline$D U L$ & 0.03 & 0.11 & 0.06 & 0.14 \\
\hline$F C$ & -0.21 & -0.10 & -0.21 & -0.10 \\
\hline$M B$ & -0.08 & $0.13^{* *}$ & -0.02 & -0.07 \\
\hline$D Y$ & 0.01 & -0.02 & 0.01 & -0.01 \\
\hline$R O E$ & $0.02 *$ & $0.04 * * *$ & $0.03 *$ & $0.06 * * *$ \\
\hline$F S$ & $0.06^{* * *}$ & $0.07 * *$ & $0.06 * *$ & $0.11 * * *$ \\
\hline$L E V$ & $0.01 * * *$ & $0.02 * * *$ & $0.01 * * *$ & $0.01 * * *$ \\
\hline BANKS & & & $-1.37 * *$ & -0.08 \\
\hline GOODS & & & $-0.99 * * *$ & -0.63 \\
\hline INDUSTRIAL & & & $-1.27 * * *$ & -0.44 \\
\hline INSURANCE & & & $-1.82 * * *$ & 0.46 \\
\hline REALSTATE & & & -0.30 & $0.74 *$ \\
\hline TELEC & & & Reference sector & Reference sector \\
\hline TRANSPORT & & & -0.41 & 0.60 \\
\hline Intercept & $4.87 * * *$ & $2.87 * *$ & $4.81 * * *$ & $2.92 * *$ \\
\hline R-squared & 0.40 & 0.36 & 0.51 & 0.43 \\
\hline F test & $30.44 * * *$ & $47.34 * * *$ & $40.89 * * *$ & $38.05 * * *$ \\
\hline
\end{tabular}

See Table 1 for the variable definitions

$* * *$ denotes $1 \%$, ** denotes $5 \%$, and $*$ denotes $10 \%$ level of significance. 
Table 5: Financial Vs Nonfinancial Firms

\begin{tabular}{|c|c|c|c|c|}
\hline & \multicolumn{2}{|c|}{ Panel A: Financial Firms } & \multicolumn{2}{|c|}{ Panel B: Nonfinancial Firms } \\
\hline & Future disclosure & Risk disclosure & Future disclosure & Risk disclosure \\
\hline FO & $1.48 * * *$ & -0.11 & $1.44 * * *$ & 0.12 \\
\hline$B C$ & -0.11 & $-0.82 * *$ & -0.05 & -0.16 \\
\hline$D U L$ & 0.14 & $0.91 * * *$ & 0.04 & -0.26 \\
\hline$F C$ & $-0.25^{* *}$ & -0.17 & -0.13 & 0.04 \\
\hline$M B$ & -0.05 & 0.02 & -0.05 & $-0.16^{* * *}$ \\
\hline$D Y$ & 0.01 & -0.01 & -0.01 & -0.05 \\
\hline$R O E$ & 0.85 & $3.71 *$ & 0.01 & $0.46^{* * *}$ \\
\hline$F S$ & $0.10^{* * *}$ & $0.09 * * *$ & $-0.03 * *$ & 0.02 \\
\hline$L E V$ & $0.02 * *$ & $0.02 * * *$ & 0.01 & $0.01 *$ \\
\hline Intercept & $3.53 * * *$ & $3.65 * *$ & $3.59 * * *$ & 1.13 \\
\hline$R$-squared & 0.68 & 0.56 & 0.29 & 0.19 \\
\hline F test & $34.99^{* * *}$ & $15.79^{* * * *}$ & $24.42 * * *$ & $8.18 * * *$ \\
\hline
\end{tabular}

See Table 1 for the variable definitions

Note: $* * *$ denotes $1 \%$, ** denotes $5 \%$, and $*$ denotes $10 \%$ level of significance. 